\section{Staphylococcus aureus 2064 growth as affected by tempera- ture and reduced water activity}

\author{
Alžbeta Medved'ová, ${ }^{1}$ Adriana \\ Havlíková, ${ }^{2}$ Veronika Lehotová, ${ }^{1}$ \\ Lubomír Valík
}

${ }^{1}$ Department of Nutrition and Food

Quality Assessment, Faculty of Chemical and Food Technology, Slovak University of Technology, Radlinského; ${ }^{2}$ Military Institute of Hygiene and Epidemiology, Ministry of Defense, Bratislava, Slovak Republic

\begin{abstract}
Based on 247 growth data, the growth of $S$. aureus 2064 in dependence on temperatures $\left(8-50^{\circ} \mathrm{C}\right)$ and $a_{w}$ values $(0.999-0.83)$ was described. Optimal values of $a_{w}$ at all studied temperatures were determined by using Gibson model. Its compatibility was confirmed by several statistical indices, e.g. root mean square errors (RMSE 0.003$0.138)$, standard errors of prediction (\%SEP 0.6-17.5). Cardinal values for $S$. aureus growth $\quad\left(T_{\min }=7.7^{\circ} \mathrm{C}, \quad T_{\text {opt }}=40.6^{\circ} \mathrm{C}\right.$, $T_{\max }=46.7^{\circ} \mathrm{C}, \quad a_{\text {wmin }}=0.808, \quad a_{\text {wopt }}=0.994$, $\mu_{o p t}=1.971 / \mathrm{h}$ ) were determined by using $\mathrm{CM}$ model with indices $R M S E=0.071$, $S E P=17.5 \%$. Our findings can provide relevant growth information that can be used in S. aureus exposure assessment or in validation of other data regarding the growth of this opportunistic pathogen in foods.
\end{abstract}

\section{Introduction}

In the traditional way of production of some cheese's varieties, raw milk is used. Thanks to the ubiquitous presence of coagulase-positive staphylococci in raw milk, also Staphylococcus aureus may be present. Its growth and potential production of 23 different types of heat-stable enterotoxins (SEs) with respect to food matrices and environmental conditions represent a potential risk to public health resulting in foodborne staphylococcal outbreaks. Besides SEs, $S$. aureus also disposes of other pathogenic factors - surface associated factors, enzymes and toxins (Asperger and Zangerl, 2003) that all contribute to the remarkable potential of $S$. aureus as a pathogen of human and animals. Moreover, this potential is multiplied by frequent occurrence of $S$. aureus in environment. In primary production and dairy environments, animals, people and operational environments are the main sources of a product's contamination by $S$. aureus. One third of human population is asymptomatic carrier of $S$. aureus, so this microorganism can contaminate foods through food handlers' cross-contamination (infected wounds, skin lesions) or by coughing and sneezing (Baird-Parker, 2000). Following contamination of food matrices, further destiny of microorganisms is dependent on the actual environmental factors. The knowledge of their effects on the pathogens growth is crucial to control their behavior (McCann et al., 2003) and consecutively to ensure microbiological safety of foods. A scientific basis of the HACCP concept and quantitative microbial risk assessment provides predictive microbiology that is based on a mathematical relationship between microbial growth responses and environmental factors (Mellefont et al., 2003). Such a knowledge may help to estimate the growth of microorganisms i) in the context of food safety (Ingham et al., 2009) or e.g. Listeria monocytogenes (Cornu et el., 2011) or ii) in the context of food spoilage (Pin et al., 1999) and extended shelf-life (Gougouli et al., 2011).

The nutritional requirements of $S$. aureus are complex and vary from strain to strain (Asperger and Zangerl, 2003). A characteristic feature which distinguishes $S$. aureus from other pathogenic bacteria is its high tolerance to low water activity $\left(a_{w}\right)$ values and $\mathrm{NaCl}$ concentrations of up to $20 \%$. Generally, minimal $a_{w}$ required for $S$. aureus growth is 0.83-0.86 (Medved'ová and Valík, 2012). Ability of $S$. aureus to grow at such high salt concentrations is related to its adaptive response to osmotic stress. This is due to the intracellular accumulation of compatible solutes, including proline, betaine, choline, taurine, or by their transport from a growth medium (O'Byrne and Booth, 2002). There is a variety of transport systems, activated/induced by $\mathrm{NaCl}$, which are responsible for entry of osmoprotectants into the cell. Besides the accumulation of compatible solutes (e.g. proline, betaine, choline, taurine) to maintain intracellular turgor pressure in response to high osmolarity environments, $S$. aureus also responds to $\mathrm{NaCl}$ stress by altering specific gene and protein expression (Scybert et al., 2003).

Several $S$. aureus growth data determined in both artificial media and in foods are present in databases. However, the majority of them do not provide $S$. aureus growth parameters in the whole growth range of selected environmental factors or a combination of several environmental factors. Uniformity of specific growth rates $(0.163 \pm 0.0251 / \mathrm{h})$ of 64 different $S$. aureus
Correspondence: Alžbeta Medved'ová, Department of Nutrition and Food Quality Assessment, Faculty of Chemical and Food Technology, Slovak University of Technology, Radlinského 9, 81237 Bratislava, Slovakia.

Tel.: +421259325524

E-mail: alzbeta.medvedova@stuba.sk

Key words: Secondary growth model, Salt addition, Cardinal temperature.

Acknowledgements: We would like to thank Kevin Slavin for checking the English in the manuscript.

Conflict of interest: The authors declare no conflict of interest.

Funding: This work was funded by grants VEGA No. 1/0532/18.

Received for publication: 16 May 2019.

Revision received: 12 August 2019.

Accepted for publication: 28 August 2019

This work is licensed under a Creative Commons Attribution-NonCommercial 4.0 International License (CC BY-NC 4.0).

CCopyright: the Author(s), 2019

Licensee PAGEPress, Italy

Italian Journal of Food Safety 2019; 8:8287

doi:10.4081/ijfs.2019.8287

strains all isolated from raw milk cheeses was confirmed by coefficient of variance $v_{c}=15.5 \%$ in Medved'ová et al. (2014) supposing uniformity of whole species responses to environmental factors. Also, the similarity of growth rates between isolate 2064 and enterotoxinogenic $S$. aureus 14733 isolated from milk vending machine biofilm was confirmed (Medved'ová et al., 2017). Based on that, the main objective of this study was to provide additional data of $S$. aureus 2064 isolated from specific artisanal raw milk cheese that can be used in the validation of $S$. aureus growth already determined. The preliminary results of salt addition effect at only 15 and $18^{\circ} \mathrm{C}$ were published by Medved'ová et al. (2009). So, the main objective of this work is to characterize the growth of $S$. aureus isolate in dependence on $a_{w}$ (adjusted by $\mathrm{NaCl}$, as the main food preservative) and in whole temperature range, and subsequently to determine cardinal environmental factors. In this connection, these data may be taken into consideration in prediction of additional growth studies of various isolates from specific foods and food environment that may contribute to reliable assessing of the variability of $S$. aureus growth dynamic under specific conditions. 


\section{Materials and Methods}

\section{Microorganism}

S. aureus 2064 isolate was selected for this study. It was isolated from ewes' lump cheese by MVDr. Hanzélyová (State Veterinary and Food Institution, Prešov, Slovakia) in 2009 by using cultivation method on selective Baird-Parker agar according to EN ISO 6888-1. Its identity was confirmed by Medved'ová et al. (2009), however the isolate does not produce enterotoxins.

\section{Media}

The isolate was maintained between experiments on Plate Count Agar slopes (PCA; Sigma-Aldrich, St. Louis, USA) at $6 \pm 1^{\circ} \mathrm{C}$ and stored for months at $-40^{\circ} \mathrm{C}$. A standard $S$. aureus 2064 inoculum $(0.3 \mathrm{~mL}$ from $10^{3}$ dilution of an $18 \mathrm{~h}$ culture grown on PCA agar at $37^{\circ} \mathrm{C}$ ) was inoculated aseptically into $300 \mathrm{~mL}$ of pre-tempered PCA broth (Difco; Le Pont de Claix, France) to reach initial $S$. aureus counts as close as possible to $10^{3} \mathrm{CFU} / \mathrm{mL}$. The samples were incubated in three parallels and repetitions at static aerobic conditions at 8, 10, 12, 15, $18,21,25,30,35,37,39,43,46$ and $50^{\circ} \mathrm{C} \pm 0.5^{\circ} \mathrm{C}$ in order to study $S$. aureus 2064 growth in dependence on temperature and $a_{w}$.

\section{The effect of water activity on S. aureus 2064 growth}

The effect of $a_{w}$ on S. aureus 2064 growth was studied in three parallels and repetitions of PCA broth with adjusted $a_{w}$ value at temperatures from 8 to $50^{\circ} \mathrm{C}$ at static aerobic conditions. The $a_{w}$ values of broth were set by the $\mathrm{NaCl}$ addition (SigmaAldrich, Buchs, Switzerland) and controlled by an $\mathrm{a}_{\mathrm{w}}$-meter (Aw-Sprint TH500, Novasina, Lachen, Switzerland).

\section{Counts of $S$. aureus 2064 in growth media}

At chosen time intervals, depending on actual temperature, numbers of the isolate were determined according to ISO 48331:2013 on PCA agar.

\section{Fitting the growth curves and pri- mary modeling}

S. aureus 2064 growth parameters were analyzed, fitted and calculated using DMFit Excel Add-in package version 3.5 (ComBase managed by United States Department of Agriculture-Agricultural Research Service, Washington, USA and University of Tasmania Food Safety Centre Hobart, Australia) that incorporates the mechanistic model of Baranyi and Roberts (1994). The actual counts were plotted against time and fitted to a model for the estimation of $\mu$ (specific growth rate), $\Delta N$ (S. aureus 2064 growth increase in stationary phase against initial density). Growth parameters from the individual parallel experiments were further analyzed by the secondary models using the Microsoft Office, version 2007 (Microsoft, Redmond, USA) and the Statistica data analysis software system, version 8.0 (Statsoft, Inc., Tulsa, USA).

\section{Secondary modeling}

The specific growth rate was firstly modeled as a function of $a_{w}$ according to Gibson et al. (1994). Using the model described by the following formula

$\ln \mu=C_{0+} C_{1} b_{w}+C_{2} b^{2}{ }_{w}$

the optimum $a_{w}$ value at each temperature for the maximum growth rate can be calculated as follows:

$$
a_{w o p t}=1-\left(\frac{C_{1}}{2 C_{2}}\right)^{2}
$$

Indices $\mathrm{C}_{0}, \mathrm{C}_{1}$ and $\mathrm{C}_{2}$ where estimated by linear regression and $a_{\text {wopt }}$ is the value of $a_{w}$ at which the maximum specific growth rate equals its optimal value $\mu_{\text {opt }}$. The parameter $b_{w}$ is calculated as:

$$
b_{w}=\sqrt{1-a_{w}}
$$

Cardinal model $\mathrm{CM}$ was used to describe the cumulative influence of temperature and $a_{w}$ on the microbial growth rate. The specific growth rate was subjected to secondary modelling in relation to the incubation temperature (Rosso et al., 1993). The combined effect of temperature and $a_{w}$ was determined according to the gamma concept (Zwietering et al., 1991), based on individual cardinal models (Rosso et al., 1993):

$$
\mu_{\max }\left(T, a_{w}\right)=C M\left(T, a_{w}\right)=\mu_{o p t} \cdot \tau(T) \cdot \gamma\left(a_{w}\right)
$$

where

$$
\tau(T)=\frac{\left(T-T_{\max }\right)\left(T-T_{\min }\right)^{2}}{\left(T_{o p t}-T_{\min }\right)\left[\left(T_{o p t}-T_{\min }\right)\left(T-T_{o p t}\right)\right.}
$$

and

$$
\begin{aligned}
\gamma\left(a_{w}\right)= & \frac{\left(a_{w}-a_{w, \max }\right)\left(a_{w}-a_{w, \min }\right)^{2}}{\left(a_{w, o p t}-a_{w, \min }\right)\left[\left(a_{w, o p t}-a_{w, \min }\right)\left(a_{w}-a_{w, o p t}\right)-\right.} \\
& \left.\left(a_{w, o p t}-a_{w, \max }\right)\left(a_{w, o p t}+a_{w, \min }-2 a_{w}\right)\right]
\end{aligned}
$$

where $T_{\text {opt }}$ is the temperature at which the maximum specific growth rate equals its optimal value $\mu_{\text {opt }}$. The cardinal values of temperature and $a_{w}$ were subsequently defined by nonlinear regression as the equation parameters.

\section{Validation of the growth parameters}

To evaluate goodness of fit of the mathematical equations describing $S$. aureus responses to the various temperature and $a_{\mathrm{w}}$ conditions, several mathematical and statistical indices were used. The regression coefficient $\left(R^{2}\right)$ and the root mean square error (RMSE; as the average deviation between observed and predicted values) was calculated according to Garcia et al. (2011), the per cent variance $(\% V$; as a measure of the goodness of the model fit) was used as was given by Daughtry et al. (1997). Finally, the bias $\left(B_{f}\right)$ and discrepancy $\left(\% D_{f}\right)$ factors as defined by Baranyi et al. (1999) were used. The indices were calculated according equations:

$$
\begin{aligned}
& \text { RMSE }=\sqrt{\frac{\sum_{i=1}^{n}\left(\mu_{o b s}-\mu_{\text {pred }}\right)^{2}}{n}} \\
& \% V=\left[1-\frac{\left(1-R^{2}\right)(n-1)}{\left(n-N_{T}-1\right)}\right] \times 100
\end{aligned}
$$

$B f=\exp \frac{\sum_{i=1}^{n}\left(\ln \mu_{p r e d}-\ln \mu_{o b s}\right)}{n}$

$$
\begin{aligned}
& \% D f=(A f-1) \times 100= \\
& \exp \sqrt{\frac{\sum_{i=1}^{n}\left(\ln \mu_{p r e d}-\ln \mu_{o b s}\right)^{2}}{n}}
\end{aligned}
$$

where $\mu_{o b s}$ and $\mu_{\text {pred }}$ are observed and predicted values of the specific growth rates, $n$ is number of the data points, $N_{T}$ is number of model terms, $A f$ is accuracy indices.

\section{Results and Discussion}

Study of $a_{w}$ and incubation temperature effect on $S$. aureus 2064 growth dynamic

The effect of the $a_{\mathrm{w}}$ and incubation temperature (at gradually ranked temperatures from $8^{\circ} \mathrm{C}$ to $50^{\circ} \mathrm{C}$ ) on the $S$. aureus 2064 growth dynamic was described in model media (PCA broth). The $a_{w}$ values of the tested media were adjusted by $\mathrm{NaCl}$, using its addition in the range from $0 \%$ up to $21 \%$, and subsequently expressed as the actual $a_{\mathrm{w}}$ value. The initial $S$. aureus 2064 concentration in all experiments $(n=307)$ was $3.20 \pm 0.23 \log \mathrm{CFU} / \mathrm{mL}$ with $c_{v}=7.35 \%$ where coefficient of variance is dependent on standard deviation and average specific growth rate value as 
$c_{v}=s_{d} / \bar{\mu} \times 100 \%$

- which was necessary for comparing the growth ability of the tested isolate under changing environmental conditions. On the other hand, the counts in stationary phase were strongly dependent on the incubation temperature and/or salt addition.

The growth parameters obtained from primary growth curves are summarized in Table 1. Generally, growth of isolate 2064 was faster as more optimal incubation temperature and $a_{\mathrm{w}}$ values were reached. Also, by increasing the incubation temperature, $S$. aureus 2064 tolerated more drastic conditions as expressed by lower minimal $a_{\mathrm{w}}$ val- ues at which it grew. Since isolate 2064 was incubated at $8^{\circ} \mathrm{C}$, it could not resist either the $\mathrm{NaCl}$ addition or the temperature of $8^{\circ} \mathrm{C}$ itself. These findings are in accordance with Normanno et al. (2005) who also did not observe growth of $S$. aureus at $8^{\circ} \mathrm{C}$. However, according Valero et al. (2009), $S$. aureus grew at $8^{\circ} \mathrm{C}, a_{w}=0.989(2 \%$ of $\mathrm{NaCl})$ and $\mathrm{pH}<6$ in $50 \%$ of cases, while at $a_{w}$ levels below 0.983 , its growth was only observed at $p H$ values 6.0-7.0. Also, Valík and Görner (1993) reported that the ability of $S$. aureus to resist high salt concentration is strain dependent, since the minimal $a_{w}$ value for growth in their experiments ranged from 0.93 to 0.86 . At $10^{\circ} \mathrm{C}$ and $12^{\circ} \mathrm{C}, \mathrm{S}$. aureus 2064 was able to grow until the $\mathrm{NaCl}$ concentration of $5 \%\left(a_{w}=0.968\right)$ and $8 \%\left(a_{w}=0.951\right)$, in order. However, its dying at these temperatures was observed at $\mathrm{NaCl}$ additions higher than $8 \%\left(a_{w}=0.951\right)$ or $10 \%\left(a_{w}=0.928\right)$. Contrary, no growth at $10^{\circ} \mathrm{C}$ and $a_{w}=0.971$ was reported by Castillejo-Rodríguez et al. (2002) and at $12^{\circ} \mathrm{C}$ and $a_{w}=0.950$ as reported Buchanan et al. (1993). Also, Lee at al. (1977) observed that $S$. aureus did not grow at $12^{\circ} \mathrm{C}$ and $a_{w}=0.915(13 \%$ of $\mathrm{NaCl})$. As reported Valero et al. (2009), resistance of $S$. aureus to low $a_{w}$ values at $19^{\circ} \mathrm{C}$ was shown, since the growth was detected at $p H 7.0$ and $a_{w}=0.867$. In our case, $S$. aureus 2064 was

Table 1. S. aureus 2064 growth parameters in relation to the incubation temperature and $a_{w}$.

\begin{tabular}{|c|c|c|c|c|c|c|c|c|c|c|c|}
\hline $\mathrm{T}$ & $a_{w}$ & $\boldsymbol{\mu}$ & $\Delta_{N}$ & $\mathrm{~T}$ & $a_{w}$ & $\mu$ & $\Delta_{N}$ & $\mathrm{~T}$ & $a_{w}$ & $\mu$ & $\Delta_{N}$ \\
\hline 8 & 0.998 & $-0.004 *$ & $-1.66^{*}$ & 21 & 0.890 & 0.026 & 4.35 & 37 & 0.913 & 0.509 & 4.15 \\
\hline 8 & 0.989 & $-0.0004^{*}$ & $-0.24^{*}$ & 21 & 0.871 & $-0.023^{*}$ & $-1.62 *$ & 37 & 0.894 & 0.427 & 3.60 \\
\hline 8 & 0.972 & $-0.003 *$ & $-0.77^{*}$ & 25 & 0.988 & 0.737 & 5.67 & 37 & 0.880 & 0.224 & 3.76 \\
\hline 10 & 0.997 & 0.044 & 4.27 & 25 & 0.977 & 0.622 & 5.27 & 37 & 0.860 & 0.152 & 3.71 \\
\hline 10 & 0.989 & 0.029 & 3.46 & 25 & 0.955 & 0.547 & 5.16 & 37 & 0.855 & $-0.025^{*}$ & $-2.15^{*}$ \\
\hline 10 & 0.968 & 0.035 & 5.04 & 25 & 0.941 & 0.534 & 4.26 & 39 & 0.998 & 1.867 & 5.75 \\
\hline 10 & 0.951 & $-0.002 *$ & $-0.98 *$ & 25 & 0.917 & 0.319 & 3.77 & 39 & 0.994 & 1.863 & 5.75 \\
\hline 12 & 0.992 & 0.064 & 4.33 & 25 & 0.894 & 0.138 & 4.75 & 39 & 0.966 & 1.502 & 5.24 \\
\hline 12 & 0.988 & 0.092 & 4.59 & 25 & 0.879 & 0.092 & 4.20 & 39 & 0.947 & 1.132 & 4.97 \\
\hline 12 & 0.969 & 0.063 & 4.50 & 25 & 0.865 & 0.037 & 3.79 & 39 & 0.930 & 1.014 & 4.68 \\
\hline 12 & 0.955 & 0.048 & 5.02 & 25 & 0.859 & $-0.261^{*}$ & $-2.19 *$ & 39 & 0.909 & 0.627 & 4.24 \\
\hline 12 & 0.928 & $-0.005^{*}$ & $-0.95^{*}$ & 30 & 0.987 & 0.968 & 5.00 & 39 & 0.894 & 0.554 & 3.75 \\
\hline 12 & 0.909 & $-0.006 *$ & $-1.28 *$ & 30 & 0.983 & 1.062 & 4.89 & 39 & 0.862 & 0.223 & 3.63 \\
\hline 15 & 0.998 & 0.155 & 5.76 & 30 & 0.969 & 0.923 & 5.15 & 39 & 0.842 & $-0.003^{*}$ & $-1.48 *$ \\
\hline 15 & 0.992 & 0.162 & 5.79 & 30 & 0.953 & 0.732 & 5.04 & 43 & 0.997 & 1.744 & 5.38 \\
\hline 15 & 0.966 & 0.114 & 5.09 & 30 & 0.930 & 0.510 & 4.73 & 43 & 0.985 & 1.801 & 5.07 \\
\hline 15 & 0.945 & 0.073 & 5.13 & 30 & 0.896 & 0.221 & 4.74 & 43 & 0.965 & 1.274 & 4.49 \\
\hline 15 & 0.923 & 0.052 & 4.37 & 30 & 0.883 & 0.219 & 4.14 & 43 & 0.945 & 1.114 & 3.80 \\
\hline 15 & 0.904 & 0.012 & 4.10 & 30 & 0.868 & 0.087 & 3.82 & 43 & 0.925 & 0.714 & 3.68 \\
\hline 15 & 0.888 & $-0.005^{*}$ & $-0.84^{*}$ & 30 & 0.856 & $-0.004^{*}$ & $-2.19 *$ & 43 & 0.913 & 0.521 & 3.19 \\
\hline 15 & 0.865 & $-0.005^{*}$ & $-0.87 *$ & 35 & 0.993 & 1.632 & 5.58 & 43 & 0.889 & 0.449 & 2.98 \\
\hline 18 & 0.988 & 0.304 & 4.69 & 35 & 0.997 & 1.602 & 5.11 & 43 & 0.860 & 0.089 & 2.92 \\
\hline 18 & 0.983 & 0.280 & 4.87 & 35 & 0.966 & 1.236 & 5.05 & 43 & 0.840 & $-0.020^{*}$ & $-2.02 *$ \\
\hline 18 & 0.964 & 0.206 & 4.97 & 35 & 0.947 & 0.965 & 4.02 & 46 & 0.997 & -0.831 & -2.32 \\
\hline 18 & 0.944 & 0.161 & 5.21 & 35 & 0.927 & 0.965 & 4.47 & 46 & 0.991 & 0.770 & 2.56 \\
\hline 18 & 0.930 & 0.083 & 4.76 & 35 & 0.913 & 0.601 & 3.96 & 46 & 0.972 & 0.668 & 3.26 \\
\hline 18 & 0.913 & 0.061 & 4.00 & 35 & 0.886 & 0.325 & 4.35 & 46 & 0.954 & 0.395 & 2.90 \\
\hline 18 & 0.893 & 0.007 & 4.12 & 35 & 0.870 & 0.226 & 4.08 & 46 & 0.929 & 0.170 & 2.76 \\
\hline 18 & 0.869 & $-0.007 *$ & $-0.84^{*}$ & 35 & 0.863 & 0.059 & 3.30 & 46 & 0.909 & 0.088 & 2.20 \\
\hline 21 & 0.992 & 0.423 & 4.65 & 35 & 0.855 & $-0.228^{*}$ & $-2.25^{*}$ & 46 & 0.891 & $-0.055^{*}$ & $-2.06 *$ \\
\hline 21 & 0.979 & 0.431 & 4.42 & 37 & 0.993 & 1.796 & 5.38 & 50 & 0.998 & $-1.013^{*}$ & $-2.96 *$ \\
\hline 21 & 0.959 & 0.374 & 5.22 & 37 & 0.988 & 1.784 & 5.05 & 50 & 0.989 & $-0.873^{*}$ & $-2.42 *$ \\
\hline 21 & 0.943 & 0.237 & 4.97 & 37 & 0.964 & 1.558 & 4.83 & 50 & 0.971 & $-0.486^{*}$ & $-1.70^{*}$ \\
\hline 21 & 0.926 & 0.162 & 5.37 & 37 & 0.947 & 1.117 & 4.88 & & & & \\
\hline 21 & 0.908 & 0.114 & 4.45 & 37 & 0.925 & 0.654 & 4.51 & & & & \\
\hline
\end{tabular}

$T$ - incubation temperature $\left({ }^{\circ} \mathrm{C}\right), a_{w}$ - actual aw value of media, $\mu$ - specific growth rate $(1 / \mathrm{h}), \Delta_{N}-S$. aureus 2064 growth increment in stationary phase against initial density (log CFU/mL), ${ }^{*}$ decreasing of counts 
not able to grow at $18^{\circ} \mathrm{C}$ if the $\mathrm{NaCl}$ addition was higher than $15 \%\left(a_{w}=0.893\right)$.

At higher temperatures $\left(39\right.$ and $\left.46^{\circ} \mathrm{C}\right)$ a similar effect of salt presence in the growth media on $S$. aureus growth was observed. The isolate confirmed its high salt tolerance even at these temperatures. The ability of bacteria to grow at high salt conditions is related to their adaptive response to osmotic stress by the intracellular accumulation of compatible solutes or by their transport from the growth medium. It was mentioned by Vaaomonde et al. (1984) that $S$. aureus cells died relatively rapidly in the presence of $\mathrm{NaCl}$. However, a variety of transport systems, e.g. betaine (BPI and BPII) or proline (PutP) transport systems (O'Byrne and Booth (2002) are activated or induced by $\mathrm{NaCl}$ and are responsible for entry of osmoprotectants (betaine, proline etc.) into the cell. Besides that, $S$. aureus may also undergo an extensive program of gene and proteins expression in response to $\mathrm{NaCl}$ stress (Scybert et al., 2003) or temperature stress (Rigoulay et al., 2004). It was shown that HtrA proteins (heat shock-induced envelope-associated serine proteases) are essential for bacteria to survive at high temperatures (Lipinska et al., 1990) and that they are responsible for degradation of denatured proteins produced at high temperatures and or under osmotic stress (Rigoulay et al., 2004).

Interestingly, isolate 2064 was not able to grow at $46^{\circ} \mathrm{C}$ in media without $\mathrm{NaCl}$. But $2 \% \mathrm{NaCl}$ addition $\left(a_{w}=0.991\right)$ into PCA broth caused that $S$. aureus 2064 started to grow and it grew only till $5 \log$ counts. The final $\mathrm{NaCl}$ concentration at which the microorganism was able to multiply at $46^{\circ} \mathrm{C}$ was $13 \% \mathrm{NaCl}\left(a_{w}=0.909\right)$. Studies have shown that in most cases a reduced $a_{w}$ leads to an increase in thermotolerance (O'Byrne and Booth, 2002). Shebuski et al. (2000) observed the similar protective effect when $S$. aureus was heat treated in the presence of increasing salt concentrations. Santoro et al. (1992) reported that activation energy of water molecules is higher in presence of heat and so they have a potent ability to interact with proteins and accelerate their duration. O'Byrne and Booth (2002) have also found that increased proteins thermostability is frequently observed when the $a_{w}$ value of the solvent is reduced, and that compatible solutes enhance thermostability. Cebrián et al. (2010) observed that $48^{\circ} \mathrm{C}$ was the last most protective heat-shock temperature for $S$. aureus in terms of developed thermotolerance. In our case, at $50^{\circ} \mathrm{C}$ no growth of $S$. aureus 2064 was detected at all.

\section{Secondary modeling}

Firstly, to describe the $a_{w}$ effect on $S$. aureus 2064 specific growth rate at each incubation temperature in PCA broth, the model of Gibson et al. (1994) was used. Equations for $S$. aureus 2064 growth dynamic responses as a function of $a_{w}$ values at all incubation temperatures are summarized in Table 2 with graphical representations depicted in Figure 1. By using this model, the optimal $a_{w}$ values for $S$. aureus 2064 in PCA broth at each single incubation temperature can be calculated as it is sum- marized in Table 2. The optimal $a_{w}$ values were strongly dependent on the incubation temperature. It was also interesting that at extreme temperatures $S$. aureus required some $\mathrm{NaCl}$ in the media, as is expressed by the lower optimal $a_{w}$ values in comparison to the almost optimal incubation temperature. It can be assumed that the halophilic character of $S$. aureus is manifested in the need for some $\mathrm{NaCl}$ amount in the media to initiate the metabolism under less favorable conditions. However, in such a condition the $a_{w}$ range allowing the staphylococcal growth is more limited, as it is expressed by the higher minimal $a_{w}$ values in contrast to the higher or more optimal incubation temperature conditions.

Due the fact that the growth rate was simultaneously influenced by $a_{w}$ and incubation temperature, we used the complete gamma concept. In this case, the gamma factors for studied environmental factors were calculated to establish the cardinal model (CM, Figure 2) that was adequate to describe the effect of incubation temperature and $a_{w}$ on $S$. aureus 2064 specific growth rate. As one can see, with increases of the incubation temperature up to $40^{\circ} \mathrm{C}$, the specific growth rate increased with a constant slope. At temperatures higher than $40^{\circ} \mathrm{C}$, the growth of $S$. aureus slows down. Therefore, the curvature is observed in the optimal region, i.e. $35-40^{\circ} \mathrm{C}$. According to $\mathrm{CM}$ model and combining a global fit, seven parameters of $\mathrm{CM}$ model, i.e., cardinal temperatures $\left(T_{\min }=7.72 \pm 0.03^{\circ} \mathrm{C}\right.$, $\left.T_{\text {opt }}=40.63 \pm 0.04^{\circ} \mathrm{C}, \quad T_{\max }=46.73 \pm 0.02^{\circ} \mathrm{C}\right)$, cardinal $a_{w}$ values $\left(a_{\text {wmin }}=0.808 \pm 0.0023\right.$,
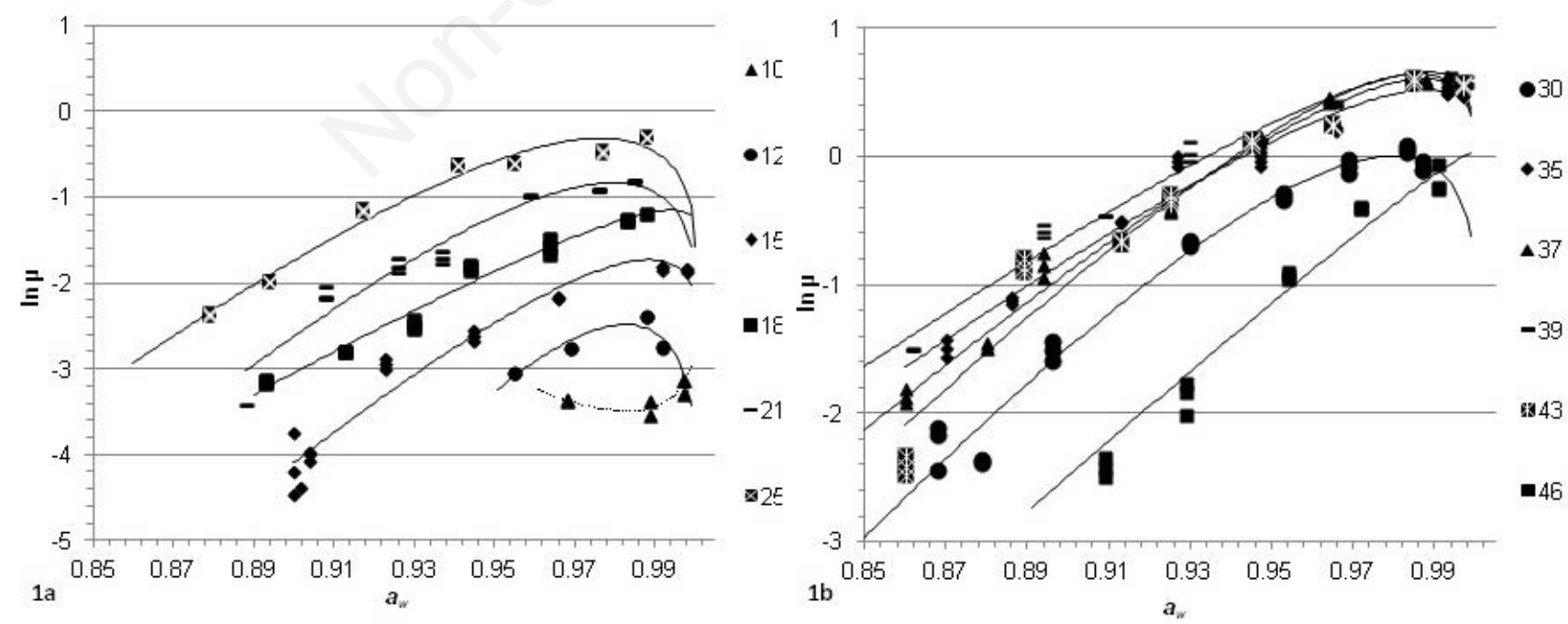

Figure 1. Plots of the natural logarithm of specific growth rates $(\ln \mu)$ versus aw for $S$. aureus 2064 . The symbols indicate the natural logarithm of the specific growth rate calculated from the growth curves at each $a_{w}$ and incubation temperature. The continuous lines indicate fitted $\ln v$ s. $a_{w}$ functions, where $b_{w}=\sqrt{\left(1-a_{w}\right)}, \mu=\exp ^{\left(c_{0} b_{w}^{2}+c_{1} \cdot b_{w}+c_{2}\right)},(1 / \mathrm{h})$ and the actual equations for each individual temperature are summarized in Table 2. 
$a_{\text {wopt }}=0.994 \pm 0.0004, a_{\text {wmax }}$ fixed to 1) and the optimal growth rate $\left(\mu_{o p t}=1.971 / \mathrm{h}\right)$ were identified. The optimal temperature of $T_{\text {opt }}=40.63^{\circ} \mathrm{C}$ seems to be high, however, according to experimental data the isolate grew with the maximal specific growth rate at $39^{\circ} \mathrm{C}$ and the model only supported this observation. Also Sutherland et al. (1994) reported temperature about $40^{\circ} \mathrm{C}$ as optimal and Taub et al. (2003) published that $S$. aureus grew in bread with the highest specific growth rate also at $40^{\circ} \mathrm{C}$. Knowing of cardinal values may increase the stability of products with increase $S$. aureus prevalence as they can help to set conditions during manufacture (heat treatment conditions), maximal allowed storage temperature ensuring no increase of $S$. aureus or maximal addition of salt leading to $S$. aureus growth inhibition. Further, the results can be also used in exposure assessment of $S$. aureus in raw milk cheeses manufactured traditionally in Slovakia as was earlier published by Ačai et al. (2014a) and Ačai et al. (2014b).

\section{Validation}

Several mathematical and statistical indices were used to validate mathematical equations describing $S$. aureus 2064 responses to environmental conditions (Table 2). In view of $R^{2}$ or more stringent term $\% V$, the worst fit $(\% V<93 \%)$ of the Gibson model to the isolate growth rate at 10 and $12^{\circ} \mathrm{C}$ was achieved. This might be accounted for the worse $S$. aureus ability to adapt to the low incubation temperature, which was also noticed during the primary growth parameters analysis. However, it is worthy of note that $\% \mathrm{~V}$ of the CM model and of the majority of Gibson models, were higher than $98 \%$. Taking into account that the smaller the RMSE, the better is the fit, the highest error is estimated by using the CM model. On the other hand, the lowest error of predictions (formulated as \%SEP) was calculated for the Gibson model at $39^{\circ} \mathrm{C}$ although the highest error is expected at $46^{\circ} \mathrm{C}$. Further, bias factor $B f<1$ indicates slower predicted growth than the observed one, and $B f>1$ indicates faster predicted growth than observed. In our case, faster growth in real media can be expected only if using Gibson model at $15^{\circ} \mathrm{C}$ and $18^{\circ} \mathrm{C}$ and in using CM model. Moreover, according to recommendation of Ross (1999) all models can be considered as acceptable since $B f$ is in range $0.90-1.05$.

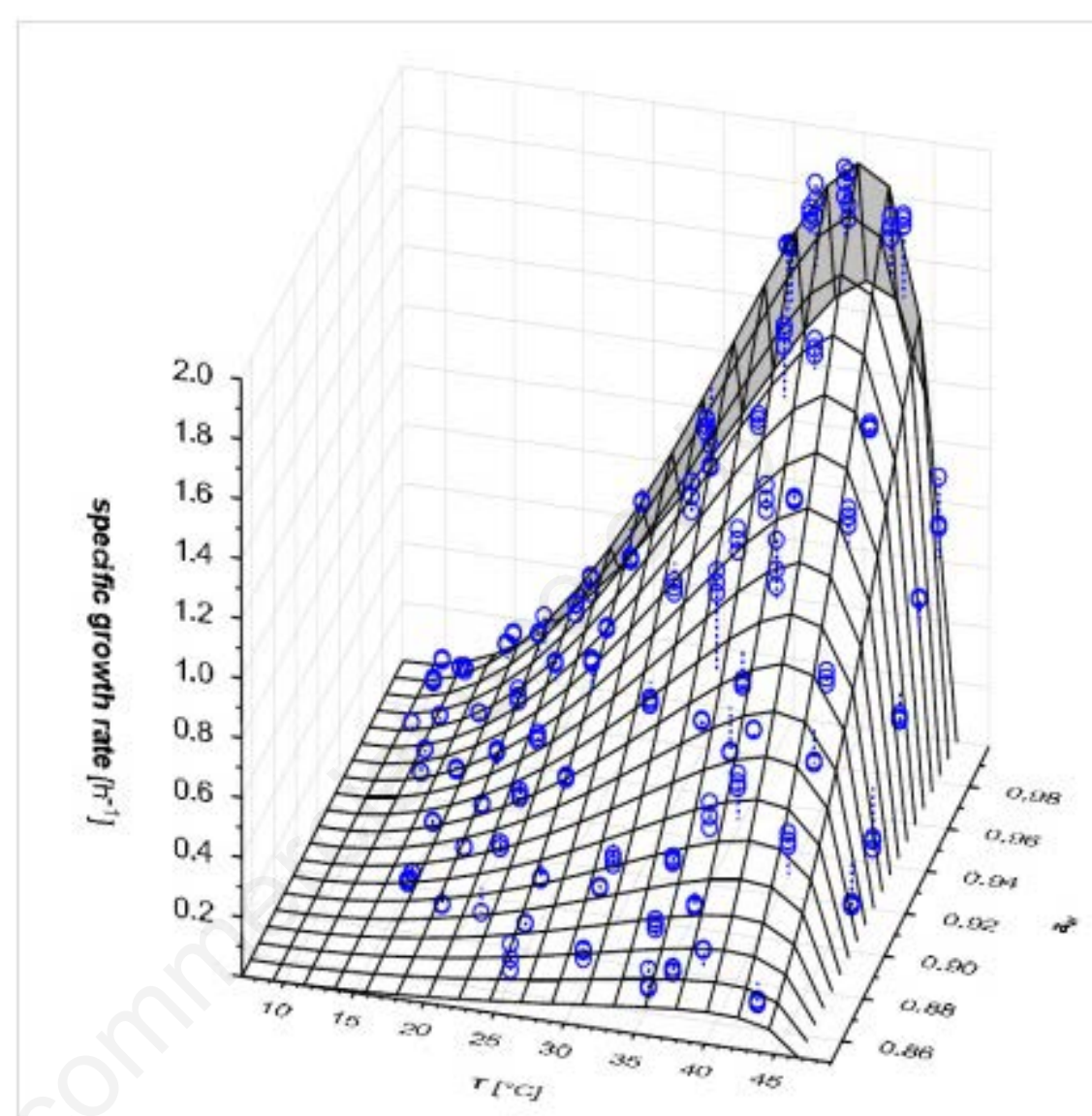

Figure 2. Graphical representation of specific growth rate responses of $S$. aureus 2064 in PCA broth as a function of temperature and aw (fitted with CM model).

Table 2. The Gibson model equations at each incubation temperature with optimal aw values or the CM model coefficients and the related indices of validation.

\begin{tabular}{|c|c|c|c|c|c|c|c|c|}
\hline Equation & n & $a_{\text {wopt }}$ & $B_{f}$ & $\% D_{f}$ & $R^{2}$ & $\% V$ & RMSE & $\% S E P$ \\
\hline $\ln \mu_{10}=53.972 b_{w}{ }^{2}-14.087 b_{w}-2.577$ & 9 & 0.982 & 0.999 & 6.9 & 0.755 & 51.0 & 0.0025 & 7.2 \\
\hline $\ln \mu_{12}=-93.792+24.711 b_{w}-4.112$ & 12 & 0.983 & 0.999 & 10.6 & 0.814 & 74.4 & 0.0077 & 12.2 \\
\hline $\ln \mu_{15}=-53.802 b_{w}{ }^{2}+11.471 b_{w}-2.342$ & 21 & 0.989 & 1.001 & 22.3 & 0.954 & 94.6 & 0.0105 & 14.8 \\
\hline $\ln \mu_{18}=-32.829 b_{w}{ }^{2}+4.961 b_{w}-1.338$ & 21 & 0.994 & 1.001 & 11.7 & 0.974 & 96.9 & 0.0142 & 9.2 \\
\hline $\ln \mu_{21}=-59.491 b_{w}{ }^{2}+16.983 b_{w}-2.048$ & 21 & 0.980 & 1.000 & 17.5 & 0.942 & 93.0 & 0.0252 & 12.8 \\
\hline $\ln \mu_{25}=-53.522 b_{w}{ }^{2}+16.387 b_{w}-1.569$ & 21 & 0.977 & 0.999 & 11.9 & 0.977 & 97.3 & 0.0616 & 11.5 \\
\hline $\ln \mu_{30}=-49.647 b_{w}{ }^{2}+14.186 b_{w}-1.013$ & 27 & 0.979 & 0.999 & 15.3 & 0.977 & 97.4 & 0.0422 & 6.8 \\
\hline $\ln \mu_{35}=-30.633 b_{w}{ }^{2}+6.652 b_{w}-0.155$ & 24 & 0.988 & 0.999 & 12.2 & 0.972 & 96.8 & 0.1113 & 11.5 \\
\hline $\ln \mu_{37}=-35.936 b_{w}{ }^{2}+8.010 b_{w}-0.159$ & 30 & 0.988 & 0.999 & 9.6 & 0.988 & 98.6 & 0.0538 & 8.2 \\
\hline $\ln \mu_{39}=-29.074 b_{w}{ }^{2}+6.191 b_{w}-0.325$ & 24 & 0.989 & 1.000 & 9.7 & 0.981 & 97.8 & 0.0067 & 0.6 \\
\hline $\ln \mu_{43}=-42.346 b_{w}{ }^{2}+10.144 b_{w}-0.035$ & 27 & 0.986 & 0.999 & 23.7 & 0.949 & 94.1 & 0.1381 & 12.7 \\
\hline $\ln \mu_{46}=-29.621 b_{w}{ }^{2}+1.486 b_{w}-0.0025$ & 21 & 0.999 & 0.931 & 22.1 & 0.976 & 96.9 & 0.0692 & 17.5 \\
\hline STA 2064: CM model & 27 & 0.0711 & 1.026 & 32.3 & 0.982 & 98.2 & 0.0711 & 17.5 \\
\hline
\end{tabular}




\section{References}

Ačai P, Valík L', Medved'ová A, Studeničová A, 2014. Staphylococcus aureus in unripened ewes lump cheese. Part 2: Exposure assessment at the time of consumption. J Food Nutr Res 53:271-7.

Ačai P, Valík L', Medved'ová A, Studeničová A, 2014. Staphylococcus aureus in unripened ewes lump cheese. Part 1: Exposure assessment after first $24 \mathrm{~h}$ of fermentation. J Food Nutr Res 53:14351.

Asperger H, Zangerl P, 2003. Staphylococcus aureus. In: Roginski H, Fuquay JW, Fox PF eds. Encyclopedia of Dairy Sciences. Academic Press, San Diego, USA, pp 2563-2569.

Baird-Parker TC, 2000. Staphylococcus aureus. In: Lund BM, Baird-Parker TC, Gould GW eds. The Microbiological Safety and Quality of Food. Aspen Publishers, Gaitherburg, USA pp 13171330.

Baranyi J, Pin C, Ross T, 1999. Validating and comparing predictive models. Int $\mathrm{J}$ Food Microbiol 48:159-66.

Baranyi J, Roberts TA, 1994. Mathematics of predictive microbiology. Int $\mathrm{J}$ Food Microbiol 26:199-218.

Buchanan RL, Smith JL, McColgan C, Marmer BS, Golden M, Dell B, 1993. Response surface models for effects of temperature, $\mathrm{pH}$, sodium chloride, and sodium nitrite on aerobic and anaerobic growth of Staphylococcus aureus 196E. J Food Safety 13:159-75.

Castillejo-Rodríguez A, García-Gimeno RM, Zurera-Cosano G, Barco-Alcalá E, Rodríguez-Pérez R, 2002. Assessment of mathematical models for predicting Staphylococcus aureus growth in cooked meat products. J Food Prot 65:659-65.

Cebrián G, Sagarzazu N, Pagán R, Condón S, Mañas P, 2010. Development of stress resistance in Staphylococcus aureus after exposure to sublethal environmental conditions. Int J Food Microbiol 140:26-33.

Cornu M, Billoir E, Bergis H, Beaufort A, Zuliani V, 2011. Modeling microbial competition in food: Application to the behavior of Listeria monocytogenes and lactic acid flora in pork meat products. Food Microbiol 28:639-74.

Daughtry BJ, Davey KR, King KD, 1997. Temperature dependence of growth kinetics of food bacteria. Food Microbiol 14:21-30.

Dengremont E, Membré JM, 1995. Statistical approach for comparison of growth rates of five Staphylococcus aureus strains. App Enviro. Microbiol 61:4839-95.

Garcia D, Ramos AJ, Sanchis V, Marín S,
2011. Modelling the effect of temperature and $a_{w}$ in growth boundaries of Aspergillus ochraceus and Aspergillus parasiticus. Food Microbiol 28:406-17.

Gibson AM, Baranyi J, Pitt JI, Eyles MJ, Roberts TA, 1994. Predicting fungal growth effect of $a_{w}$ on Aspergillus flavus and related species. Int J Food Microbiol 23:419-31.

Gougouli M, Kalantzi K, Beletsiotis E, Koutsoumanis KP, 2011. Development and application of predictive models for fungal growth as tools to improve quality control in yogurt production. Food Microbiol 28:1453-62.

Ingham SC, Ingham BH, Borneman D, Jaussaud E, Schoeller EL, Hoftiezer N, Schwartzburg L, Burnham GM, Norback JP, 2009. Predicting pathogen growth during short-term temperature abuse of raw sausage. J Food Prot 72:75-84.

Lee IC, Harmon LG, Price JF, 1977. Growth and enterotoxin production by staphylococci in Genoa salami. J Food Prot 40:325-9.

Lipinska B, Zylicz M, Georgopoulos C, 1990. The HtrA (DegP) protein, essential for Escherichia coli survival at high temperatures, is an endopeptidase. J Bacteriol 1725:1791-7.

McCann TL, Eifert JD, Gennings C, Schilling MW, Carter WH, 2003. A predictive model with repeated measures analysis of Staphylococcus aureus growth data. Food Microbiol 20:139-47.

Medved'ová A, Valík L', Studeničová A, 2009. The effect of temperature and $a_{w}$ on the growth of Staphylococcus aureus. Czech J Food Sci 27:28-35.

Medved'ová A, Valík L, 2012. Staphylococcus aureus: Characterization and Quantitative Growth Description in Milk and Artisanal Raw Milk Cheese Production. In: Eissa AA ed. Structure and Function of Food Engineering. InTech, Rijeka, Croatia pp. 71-102.

Medved'ová A, Studeničová A, Valík L, Horváthová Z, 2014. The prevalence and growth dynamic of enterotoxinogenic Staphylococcus aureus isolates in Slovakian dairy products. Czech J Anim Sci 32:337-41.

Medved'ová A, Havlíková A, Valík L', 2017. Staphylococcus aureus enterotoxin production in relation to environmental factors. In: Enamy S, Crotty LE eds. The rise of virulence and antibiotis resistance in Staphylococcus aureus. InTech, Rijeka, Croatia pp. 145-67.

Mellefont LA, McMeekin TA, Ross T, 2003. Performance evaluation of a model describing effects of temperature, $a_{w}, \mathrm{pH}$ and lactic acid concentration on the growth of Escherichia coli. Int J Food
Microbiol 82:45-58.

Normanno G, Firinu A, Virgilio S, Mula G, Dambrosio A, Poggiu A, 2005. Coagulase-positive Staphylococci and Staphylococcus aureus in food products marketed in Italy. Int J Food Microbiol 98:73-9.

O'Byrne C, Booth IR, 2002. Osmoregulation and its importance to food-borne microorganisms. Int J Food Microbiol 74:203-16.

Pin C, Sutherland JP, Baranyi J, 1999. Validating predictive models of food spoilage organisms. J App Microbiol 87:491-9.

Rigoulay C, Poquet I, Madsen SM, Gruss A, 2004. Expression of the Staphylococcus aureus surface proteins $\mathrm{Htr}_{1}$ and $\mathrm{Htr}_{2}$ in Lactococcus lactis. FEMS Microbiol Let 237:279-88.

Ross T, 1999. Indices for performance evaluation of predictive models in food microbiology. J App Microbiol 81:501-8.

Rosso L, Lobry JR, Flanders JP, 1993. An unexpected correlation between cardinal temperatures of microbial growth highlighted by a new model. J Theor Biol 162:447-63.

Santoro MM, Liu Y, Khan SMA, Hou LX, Bolen DW, 1992. Increased thermal stability of proteins in the presence of naturally occurring osmolytes. Biochemistry 31:5278-83.

Scybert S, Pechous R, Sitthisak S, Nadakavukaren MJ, Wilkinson BJ, Jayaswal RK, 2003. NaCl-sensitive mutant of Staphylococcus aureus has a Tn917-lacZ insertion in its ars operon. FEMS Microbiol Lett 222:171-6.

Shebuski JR, Vilhelmsson O, Miller KJ, 2000. Effects of growth at low $a_{w}$ on thermal tolerance of Staphylococcus aureus. J Food Prot 63:1277-81.

Sutherland JP, Bayliss AJ, Roberts TA, 1994. Predictive modelling of growth of Staphylococcus aureus: the effects of temperature, $\mathrm{pH}$ and $\mathrm{NaCl}$. Int $\mathrm{J}$ Food Microbiol 21:217-36.

Taub IA, Feeherry FE, Ross EW, Kustin K, Doona CJ, 2003. A quasi-chemical kinetics model for the gorwth and death of Staphylococcus aureus in intermediate moisture bread. Food Micro Safety 68:2530-6.

Valero A, Pérez-Rodríguez F, Carrasco E, Fuentes-Alventosa JM, García-Gimeno RM, Zurera G, 2009. Modelling growth boundaries of Staphylococcus aureus: Effect of temperature, $\mathrm{pH}$ and $\mathrm{a}_{\mathrm{w}}$. Int $\mathrm{J}$ Food Microbiol 133:186-94.

Valík L', Görner F, 1993. Growth of Staphylococcus aureus in pasta in relation to its $a_{w}$. Int J Food Microbiol 20:458. 